\title{
$\begin{array}{r}\text { WAGENINGEN } \\ \text { UNIVERSITY \& RESEARCH } \\ \hline\end{array}$
}

Forest degradation influences nesting site selection of Afro-tropical stingless

bee species in a tropical rain forest, Kenya

Kiatoko, N., Van Langevelde, F., \& Raina, S. K.

This article is made publically available in the institutional repository of Wageningen University and Research, under article 25 fa of the Dutch Copyright Act, also known as the Amendment Taverne.

Article 25 fa states that the author of a short scientific work funded either wholly or partially by Dutch public funds is entitled to make that work publicly available for no consideration following a reasonable period of time after the work was first published, provided that clear reference is made to the source of the first publication of the work.

For questions regarding the public availability of this article, please contact openscience.library@wur.nl.

Please cite this publication as follows:

Kiatoko, N., Van Langevelde, F., \& Raina, S. K. (2018). Forest degradation influences nesting site selection of Afro-tropical stingless bee species in a tropical rain forest, Kenya. African Journal of Ecology, 56(3), 669-674.

https://doi.org/10.1111/aje.12491 


\section{Forest degradation influences nesting site selection of Afro- tropical stingless bee species in a tropical rain forest, Kenya}

\author{
Nkoba Kiatoko ${ }^{1}$ (D) | Frank Van Langevelde ${ }^{2}$ \\ ${ }^{1}$ International Centre of Insect Physiology and Ecology (icipe), Nairobi, Kenya \\ ${ }^{2}$ Resource Ecology Group, Wageningen University, Wageningen, The Netherlands \\ Correspondence \\ Nkoba Kiatoko \\ Email: nkiatoko@icipe.org \\ Funding Information \\ European Union, Grant/Award Number: DCI-FOOD-2011/023-520
}

\section{1 | INTRODUCTION}

Stingless bees are found throughout most of the tropical and subtropical regions of the world (Michener, 2000; Michener \& Grimaldi, 1988; Roubik, 1989; Velthius, 1997). In Africa, 20 stingless bee species have been described so far, but their biology is largely unknown. Only few studies report on the nesting site selection of stingless bee species in Africa and how forest characteristics regulate species diversity (Kajobe \& Roubik, 2006; Tornyie \& Kwapong, 2015). Nesting site selection in stingless bees, although being species-specific (Hubbel \& Johnson, 1977; Pyper, 2001; Roubik, 1989, 2006; Sakagami, 1982; Vossler, 2012; Wille \& Michener, 1973), may be determined by the type of habitat. Globally, stingless bees display considerable diversity in nesting substrates (Roubik, 1989, 2006; Vossler, 2012). Meliponine colonies are perennial, and most nests are built in pre-existing hollows within different substrates such as tree trunks (living and dead), ground, brick walls and active nests of termites, ants or wasps. The effect of forest degradation on the diversity of stingless bees is, however, still controversial (Ewers \& Didham, 2006; Jauker, Diekötter, Schwarzbach, \& Wolters, 2009). On the one hand, removal of trees is said to negatively impact bee assemblages (Allen-wardell et al., 1998; Kearns, Inouye, \& Waser, 1998; Kremen et al., 2007) because many stingless bees nest in cavities of living trees (Kerr, Carvalho, \& Nascimento, 1999; Roubik, 2006). On the other hand, Winfree, Griswold, and Kremen (2007) reported that some anthropogenic land use may contribute to the conservation of many, but not all, bee species by offering alternative nesting substrate. It is possible that some Afrotropical stingless bee species can nest in disturbed habitat by choosing different nesting substrata than which they use in their natural habitat.

In this study, we compare the nesting sites of four meliponinae bee species over different habitats in and around Kakamega forest, Kenya, namely Hypotrigona gribodoi (Magretti, 1884), Meliponula bocandei (Spinola, 1853), Meliponula ferruginea (reddish brown morpho

\author{
Suresh Kumar Raina ${ }^{1}$
}

species) (Lepeletier, 1841), Meliponula ferruginea (black morpho species) (Smith, 1854) and Meliponula lendliana (Friese, 1900). Degradation of indigenous forests in some parts of Kakamega forest, resulting in grasslands as well as rural human settlements (Tsingalia, 1990; Tsingalia \& Kassily, 2009), might have changed the nesting site selection of these species. We explored whether the nesting site selection of each bee species change with the habitat types which could explain how they can maintain themselves in a changing environment.

\section{MATERIALS AND METHODS}

\section{1 | Study sites}

We did our study in Kakamega forest in western Kenya (between latitudes $0^{\circ} 10^{\prime}$ and $0^{\circ} 21^{\prime}$ north and longitudes $34^{\circ} 47^{\prime}$ and $34^{\circ} 58^{\prime}$ east). The natural vegetation of Kakamega forest is tropical rainforest, but nowadays the forest is an island of forest in a sea of human-dominated landscape (Muriuki \& Tsingalia, 1990). Two sites, namely lleho ivihiga and Isiekuti, were selected to study three habitat types, namely forest, grassland and homestead (i.e. a gradient of habitat degradation). At lleho ivihiga site, the forest is a natural indigenous rainforest with indigenous tree species only. The grassland next to this forest is human-disturbed dominated by grass, shrubs and many scattered Eucalyptus sp. trees. Ileho ivihiga homestead is dominated by residential houses built with mud, and their walls are smoothened using mud. At Isiekuti site, the forest is a mix of both indigenous and introduced exotic tree species. The grassland next to this mixed forest is a cattle grazing zone (Tsingalia, 1988, 1990) and is dominated by grass, shrubs and few, scattered indigenous tree species. The homestead at Isiekuti is dominated by muddy houses, and few built cement houses are also found. Walls of muddy houses are mostly smoothened using a mixture of mud and cow dung, and walls smoothened with mud only or not smoothen at all are also found. 


\subsection{Sampling method}

A total of 30 line transects of 500 metres long were used to determine nest abundance and nesting habits for the meliponine bee species in each site (Jongjitvimol, Boontawon, Wattanachaiyingcharoen, $\&$ Deowanish, 2005). Nest inspections were carried out during sunny days to facilitate viewing of forager bees flying in and out of their nests on every substrate likely to have nests, such as bare soil, living and dead trees, termite mounds, houses. For nest inspections in living or dead trees taller than six metres, a spectrum binocular (Olympus, Porro Prism Standard Binocular) was used (Eltz, Bruhl, Imiyabir, \& Linsenmair, 2003). When a nest was found, some bees flying out of the nest were collected using a sweep net, identified and recorded (Kajobe, 2007). The specimens from different nests were preserved in $70 \%$ alcohol, in separate vials coded for further identification to confirm the species. The number of nests of each meliponine species observed in the three different habitats was recorded.

The nesting location and substrata with the nests of the meliponine species were recorded (Jongjitvimol et al., 2005). The tree species in which the bee nest was built were identified by field assistants of the Kenya Forest Service and Isecheno Forest Station (Eltz et al., 2003; Kajobe, 2007). The tree substratum (trunk, branch) and its characteristic (live or dry) selected by the bee species were recorded. For nests found in houses, the nesting substratum was recorded per the type of constructing material used to build the wall (cement or mud). For muddy wall houses, the nesting substratum was recorded per the wall pattern (smoothened or unsmoothed) and material used to smoothen the wall (mud or a mixture of mud and cow dung). Lastly, the nesting substratum for underground nests was classified into termite nest, abandoned rat nest, hollow made by
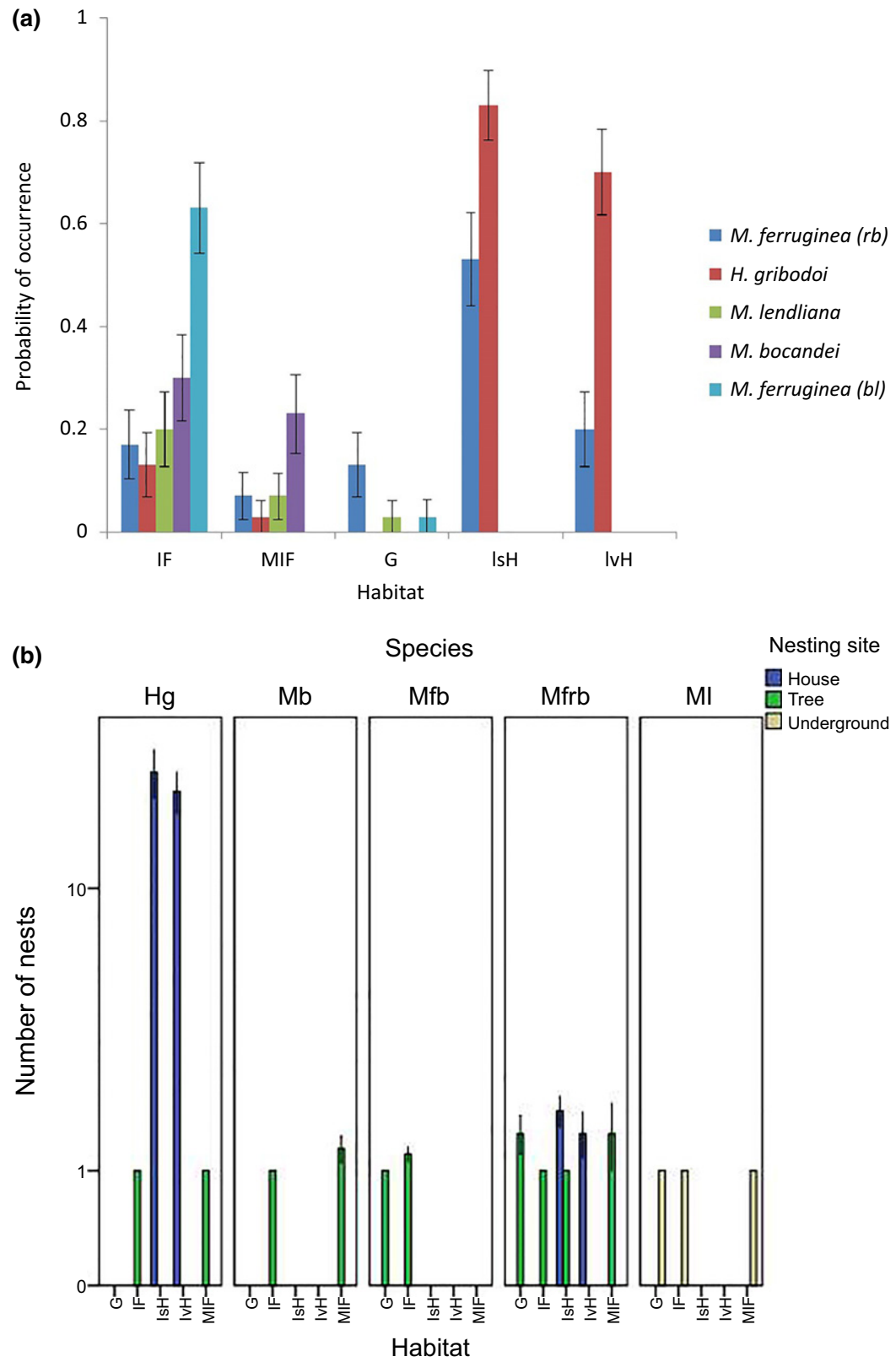

FIGURE 1 (a) Stingless bee species richness and mean probability ( $\pm 1 \mathrm{SE}$ ) of finding a nest in different habitat types. Note the logarithmic scale of the $y$-axis of panel b. Habitat types: IF, indigenous forest; MIF, mixed indigenous forest; G, grassland with scattered indigenous tree species; IsH, Isiekuti homesteads; IvH, lleho homesteads. (b) Stingless bee nesting site and mean number of nests ( $\pm 1 S E$ ) in different sites (tree, house, underground) in different habitat types. Note the logarithmic scale of the $y$-axis of panel $b$. Bee species: Mfrb, Meliponula ferruginea (reddish brown); Hg, Hypotrigona gribodoi; Mb, M. bocandei; Ml, M. lendliana; Mfb, M. ferruginea (black) [Colour figure can be viewed at wileyonlinelibrary.com] 
roots, hollow between rocks or unknown. The average height of the nest was measured according to Danaraddi, Viraktamath, Basavanagoud, and Bhat (2009). The height of the nest in trees and the wall of houses were measured from the ground surface to the nest entrance tube, and the depth of the nest underground was measured from the ground surface to the upper nest part.

\subsection{Data analysis}

To study the differences in nest occurrence of the stingless bee species over the habitat types, we first tested the differences in the presence of a nest in a habitat type using a generalized linear model (with binomial distribution and logit link function), followed by the Tukey's post hoc test. One-way analysis of variance was used to analyse differences in mean height and depth of nests between nesting sites, followed by the Tukey's post hoc test.

\section{RESULTS}

A total of 1030 nests belonging to the four meliponine species were discovered in and around Kakamega forest. Species richness largely differed between the habitat types, and we found lower richness in habitat types with degraded forest. M. ferruginea (reddish brown) morpho species nested in five different habitat types $\left(\chi^{2}=21.3\right.$; $d f=4,145 ; p<.001)$ : indigenous forest, mixed indigenous forest, grassland with scattered indigenous tree species and the homesteads (highest chance of finding a nest at Isiekuti). Differences in nest occurrence of $H$. gribodoi were observed between its four nesting habitats $\left(\chi^{2}=67.63 ; d f=3,116 ; p<.001\right)$. Both homesteads had higher nest occurrences than the indigenous and mixed indigenous forest. Nests of M. bocandei were equally found in the indigenous and mixed indigenous forests $\left(\chi^{2}=0.34 ; d f=1,58 ; p>.05\right)$. For M. ferruginea (black), there was higher occurrence of nests in the indigenous forest than in the grassland with scattered indigenous trees $\left(\chi^{2}=28.18 ; d f=1,58 ; \quad p<.001\right)$. The nest occurrence of $M$. lendliana in the indigenous forest was higher than in the mixed indigenous forest and the grassland with scattered indigenous tree species $\left(\chi^{2}=5.03 ; d f=2,87 ; p<.001\right)$ (Figure 1a).

Meliponula ferruginea (black), M. bocandei and M. lendliana did not show any tendency to nest in more than one site. Nests of $M$. ferruginea (black) and $M$. bocandei were only found in cavities in trees, while $M$. lendliana nested only in underground hollow. $H$. gribodoi and $M$. ferruginea (reddish brown) nested in more than one type. When nesting in homestead, M. ferruginea (reddish brown) selected either cavities in houses and trees, whereas they selected only trees when nesting in the indigenous forest, mixed indigenous forest and grassland with scattered indigenous tree species. When nesting in homesteads, $H$. gribodoi selected cavities in houses more frequently than in trees. M. lendliana was the only species found to be nesting underground (Figure 1b).

In trees, M. bocandei selected higher height for nesting, whereas $H$. gribodoi nested at the same height as M. ferruginea (black) and M. ferruginea (reddish brown) (ANOVA: $F_{3,117}=12.93 ; p<.001$ ). In walls of houses, no significant differences were found in the nest height between $M$. ferruginea (reddish brown) and $H$. gribodoi (ANOVA: $F_{1,152}=0.16 ; p>.05$ ) (Figure 2).

For the underground nesting species $M$. lendliana, nests were found only in cavities between roots. Nests of M. bocandei in trees were mostly sheltered in cavities located in trunks of live trees rather than in branches (Figure 3a). Nests of both M. ferruginea (black) (Figure 3b) and M. ferruginea (reddish brown) (Figure 3c) in trees were mostly found in cavities located in trunks of live trees rather than in branches. When nesting in houses, nests of
FIGURE 2 Mean nesting height for the stingless bee species per site (house, tree) ( $\pm 1 \mathrm{SE}$ ). Ml was the only species nesting underground (brown bar). Mfrb, Meliponula ferruginea (reddish brown); $\mathrm{Hg}$, Hypotrigona gribodoi; Mb, M. bocandei; Ml, M. lendliana; Mfb, M. ferruginea (black) [Colour figure can be viewed at wileyonlinelibrary.com]

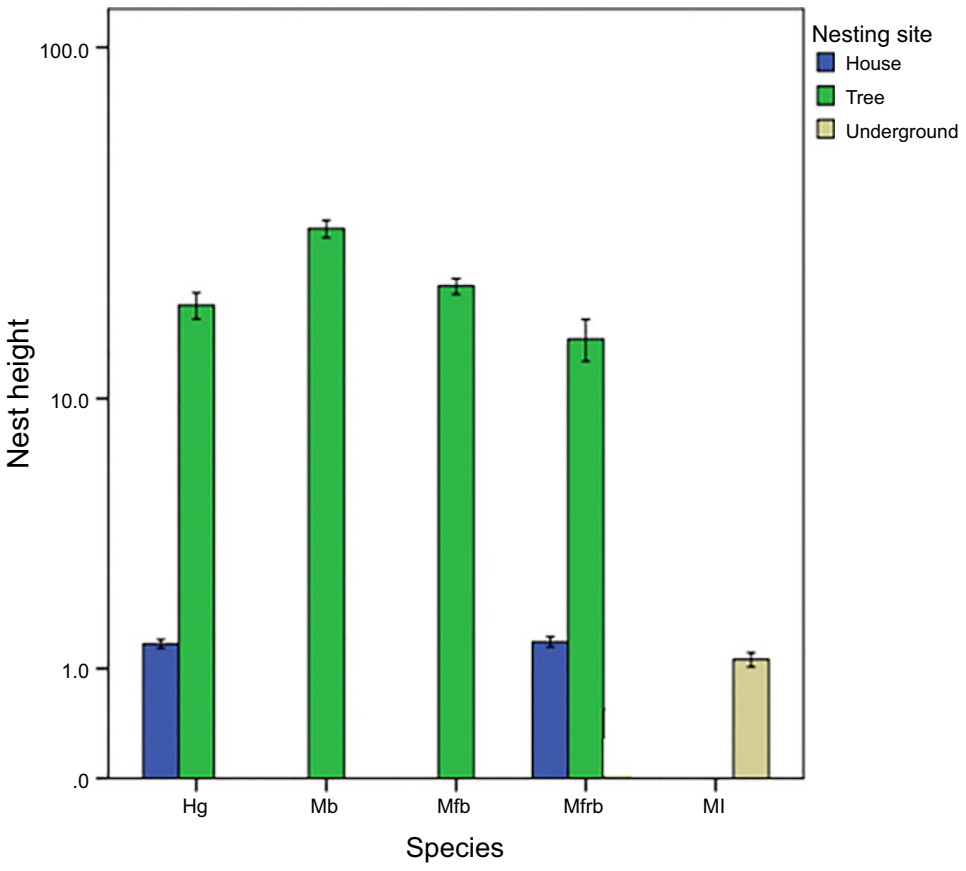



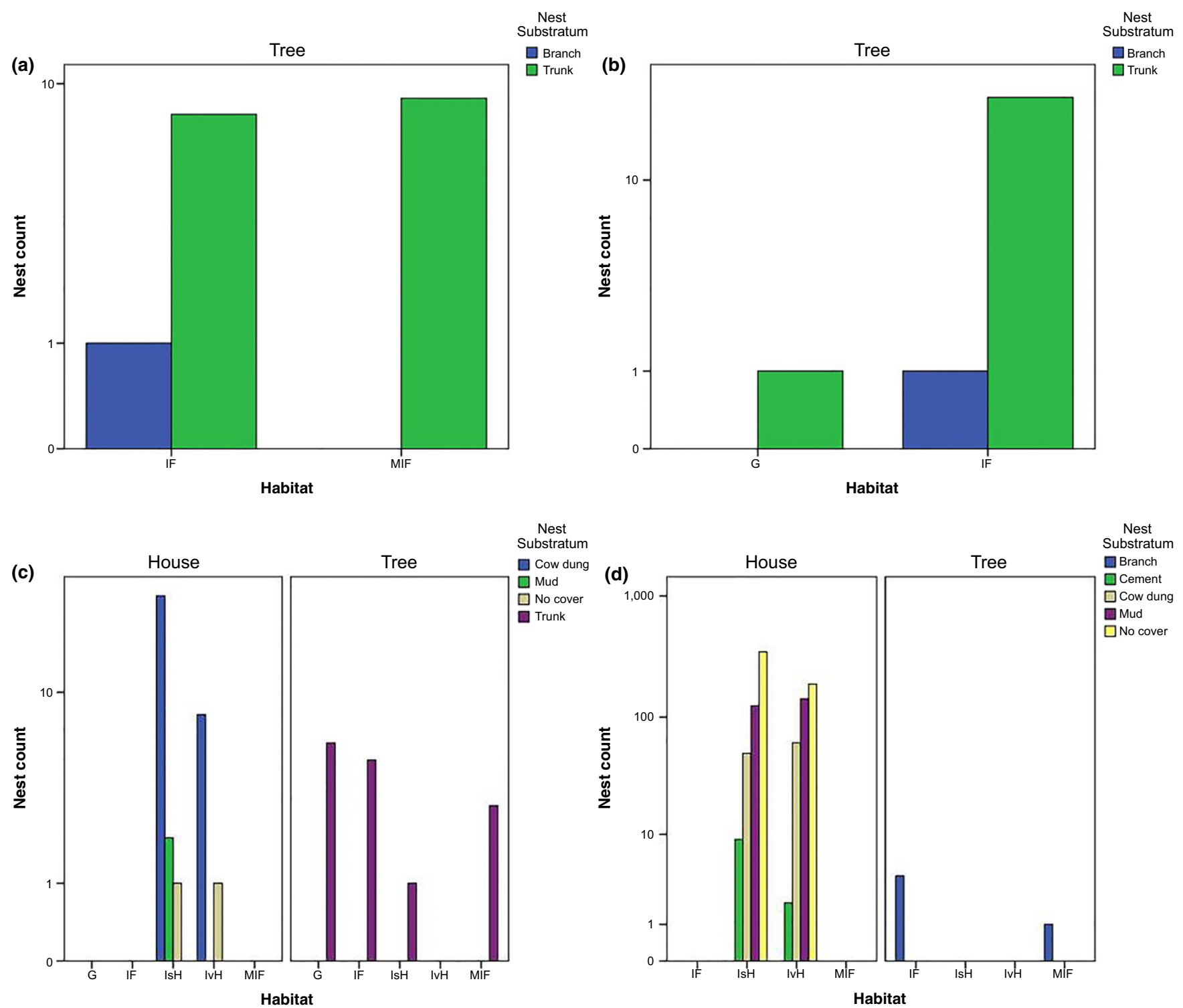

FIGURE 3 Number of nests of (a) Meliponula bocandei, (b) M. ferruginea (black), (c) M. ferruginea (reddish brown) and (d) H. gribodoi nests in different substrata in different habitat types. IF, indigenous forest; MIF, mixed indigenous forest; G, grassland with scattered indigenous tree species; IsH, Isiekuti homesteads; IvH, Ileho homesteads [Colour figure can be viewed at wileyonlinelibrary.com]

M. ferruginea (reddish brown) were mainly found in three types of substratum. Nests of $H$. gribodoi in trees were mostly found in cavities in branches of live trees rather than on trunks (Figure 3d). When nesting in houses, $H$. gribodoi was mainly found in four types of substratum and very few nests of this species were in cavities in cemented walls. In total, sixteen different tree species were identified as hosts to the four stingless bee species (Table 1).

\section{4 | DISCUSSION}

Nesting ecology of stingless bees is well studied for species in Neotropical regions compared to Afro-tropical species (Kajobe, 2007; Roubik, 2006; Vossler, 2012). The species richness of Neotropical stingless bees is reported to decrease in degraded forest
(Hubbel \& Johnson, 1977; Jongjitvimol et al., 2005). Similarly, we found that Afro-tropical stingless bee species richness decreases with habitat types. Our findings confirm previous studies that reported that meliponine bees are strongly associated with natural native forest habitats for nesting (Brosi, Daily, Shih, Oviedo, \& Duran, 2008). Introduction of exotic tree species in degraded indigenous forest and the transformation into mixed indigenous forest negatively impacted species richness (Boontop, Malaipan, Chareansom, \& Wiwatwittaya, 2008; Tornyie \& Kwapong, 2015).

In our study, M. ferruginea (reddish brown) nested in five different habitat types and $H$. gribodoi nested in four types of the six types compared to $M$. lendliana (3 types), $M$. bocandei (2 types) and M. ferruginea (black) (2 types). The fact that M. ferruginea (reddish brown) and $H$. gribodoi were nesting in almost all habitat types is an indicator that these species are more tolerant to forest degradation 
TABLE 1 The host plants used by the stingless bee species as nesting sites in and around Kakamega forest

\begin{tabular}{lll}
\hline Host plant & Host plant family & Bee species \\
\hline Croton sylvaticus & Euphorbiaceae & Mfb, Mfrb \\
\hline Croton megalocarpus & Euphorbiaceae & $\mathrm{Mb}$ \\
\hline Markhamia lutea & Bignoniaceae & $\mathrm{Hg}$ \\
\hline Spathodea campanulata & Bignoniaceae & $\mathrm{Mfb}, \mathrm{Mfrb}$ \\
\hline Celtis mildbraedii & Cannabaceae & $\mathrm{Mfrb}$ \\
\hline Celtis africana & Cannabaceae & $\mathrm{Mb}, \mathrm{Hg} . \mathrm{Mfb}$ \\
\hline Syzygium guineense & Myrtaceae & $\mathrm{Mb}$ \\
\hline Eucalyptus sp & Myrtaceae & $\mathrm{Mb}, \mathrm{Mfrb}$ \\
\hline Antiaris toxicaria & Moraceae & $\mathrm{Mb}, \mathrm{Mfrb}$ \\
\hline Zanthoxyllum macrophyllum & Rutaceae & $\mathrm{Mb}, \mathrm{Mfb}$ \\
\hline Olea capensis & Oleaceae & $\mathrm{Mb}, \mathrm{Mfb}$ \\
\hline Albizia gummifera & Fabaceae & $\mathrm{Mfb}$ \\
\hline Cordia africana & Boraginaceae & $\mathrm{Mb}$ \\
\hline Trichilia emetica & Meliaceae & $\mathrm{Mfb}, \mathrm{Mfrb}$ \\
\hline Prunus africana & Rosaceae & $\mathrm{Mfb}$ \\
\hline Diospyros abyssinica & Ebenaceae & $\mathrm{Mb}, \mathrm{Hg}, \mathrm{Mfb}, \mathrm{Mfrb}$ \\
\hline
\end{tabular}

Mfrb, Meliponula ferruginea (reddish brown); Hg, Hypotrigona gribodoi; $\mathrm{Mb}$, M. bocandei; Mfb, M. ferruginea (black).

than the three other studied species. The stingless bee species nested either in trees, underground or in walls of houses. Differences in these substrates among the habitat types in Kakamega forest lead to shifts in the nest occurrences and nesting habits of these stingless bees. Winfree et al. (2007) supported that some anthropogenic land use may be compatible with the conservation of many, but not all, bee species by specific species shifting their nesting sites. Vossler (2012) found that nests of Plebeia catamarcensis and Tetragonisca fiebrigi were commonly found in brick walls. We found this for H. gribodoi and M. ferruginea (reddish brown) nests being more abundant in homesteads due to the ability of these species to shift nesting from cavities in trees to cavities in walls of houses. This shift allows these two bee species to be able to adapt and be less affected by deforestation and reforestation using exotic tree species compared to the other three species.

Nesting sites and substrata are species specific in stingless bee species (Pyper, 2001; Roubik, 2006; Sakagami, 1982; Velthius, 1997). M. lendliana nested only in underground cavities, while M. bocandei and M. ferruginea (black) nested only in trees cavities. Nests of the tree nesting species were mostly observed in living tree parts (also found by Roubik, 1989; Antonini, 2002; Martins, Cortopassilaurino, Koedam, \& Imperatriz-fonseca, 2004), probably to escape devastation of the tree cavity by termites. $H$. gribodoi and M. ferruginea (reddish brown) nests were more abundant in homesteads, suggesting that these species can shift nesting from trees to cavities in walls of houses. We found little variation in nesting substrate for each meliponine species, which could cause the decrease in species richness in when habitat is degraded. Other studies also showed that some meliponine species appeared to be affected by deforestation
(Vossler, 2012). These species were present mainly in areas where the forest was more intact and preferred living in tree trunks for nesting (cf. Roubik, 1989).

This study indicates that there is clear value to conserve native indigenous forest habitat and to promote forest regeneration through planting indigenous tree species for the conservation of most Afro-tropical stingless bee species. Conservation of stingless bee biodiversity in the wild has become a global concern in Neotropical and Afro-tropical regions due to their ecological and economical importance.

\section{ACKNOWLEDGEMENTS}

The authors acknowledge European Union Project Fund ( $\mathrm{DCl}-$ FOOD-2011/023-520) for the generous financial support received for this research. We also acknowledge the Kenya Forest Service (Kakamega) for providing us with all the assistance on the ground during the fieldwork.

\section{ORCID}

Nkoba Kiatoko (iD http://orcid.org/0000-0001-5612-4801

Frank Van Langevelde (iD http://orcid.org/0000-0001-8870-0797

\section{REFERENCES}

Allen-wardell, G., Bernhardt, P., Bitner, R., Burquez, A., Buchmann, S., Cane, J., ... Nabhan, G. P. (1998). The potential consequences of pollinator declines on the conservation of biodiversity and stability of food crop yields. Conservation Biology, 12, 8-17.

Antonini, Y. (2002). Efeitos de variáveis ecológicas na ocorrência de Melipona quadrifasciata (Apidae, Meliponini) em fragmentos urbanos e rurais. Tese de doutorado. Universidade Federal de Minas Gerais, Belo Horizonte, Brazil.

Boontop, Y., Malaipan, S., Chareansom, K., \& Wiwatwittaya, D. (2008). Diversity of stingless bees (Apidae: Meliponini) in Thong Pha Phum District, Kanchanaburi Province, Thailand. The Kasetsart Journal (Natural Science), 42, 444456.

Brosi, B. J., Daily, G. C., Shih, T. M., Oviedo, F., \& Duran, G. (2008). The effects of forest fragmentation on bee communities in tropical countryside. Journal of Applied Ecology, 45, 773-783.

Danaraddi, C. S., Viraktamath, S., Basavanagoud, K., \& Bhat, A. R. S. (2009). Nesting habits and nest structure of stingless bee, Trigona iridipennis Smith at Dharwad, Karnataka. Karnataka Journal of Agricultural Sciences, 22(2), 310-313.

Eltz, T., Bruhl, C. A., Imiyabir, Z., \& Linsenmair, K. E. (2003). Nesting and nest trees of stingless bees (Apidae: Meliponini) in lowland dipterocarp forest in Sabah, Malaysia, with implication for forest management. Forest Ecology and Management, 172, 301-313.

Ewers, R. M., \& Didham, R. K. (2006). Confounding factors in the detection of species responses to habitat fragmentation. Biological Reviews, 81, 117-142.

Hubbel, S. P., \& Johnson, L. K. (1977). Competition and nest spacing in a tropical stingless bee community. Ecology, 58, 949-963.

Jauker, F., Diekötter, T., Schwarzbach, F., \& Wolters, V. (2009). Pollinator dispersal in an agricultural matrix: Opposing responses of wild bees and hoverflies to landscape structure and distance from main habitat. Landscape Ecology, 24, 547-555. 
Jongjitvimol, T., Boontawon, K., Wattanachaiyingcharoen, W., \& Deowanish, S. (2005). Nest dispersion of a stingless bee species, Trigona collina Smith, 1857 (Apidae, Meliponinae) in a mixed deciduous forest in Thailand. The Natural History Journal of Chulalongkorn University, 5(2), 69-71.

Kajobe, R. (2007). Nesting biology of equatorial Afrotropical stingless bees (Apidae; Meliponini) in Bwindi Impenetrable National Park, Uganda. Journal of Apicultural Research and Bee World, 46(4), 245-255.

Kajobe, R., \& Roubik, D. W. (2006). Honey-making bee colony abundance and predation by apes and humans in a Uganda Forest Reserve. Biotropica, 38(2), 1-9.

Kearns, C. A., Inouye, D. W., \& Waser, N. M. (1998). Endangered mutualisms: The conservation of plant-pollinator interactions. Annual Review of Ecology and Systematics, 29, 83-112.

Kerr, W. E., Carvalho, G. A., \& Nascimento, V. A. (1999). The probable consequences of the destruction of Brazilian stingless bees. In $\mathrm{C}$. Padoch, J. M. Ayres, M. Pinedo-Vasquez, \& A. Henderson (Eds.), Várzea: Diversity development, and conservation of Amazonia's white water floodplains (pp. 395-403). NewYork, NY: The New York Botanical Garden Press.

Kremen, C., Williams, N. M., Aizen, M. A., Gemmill-herren, B., Lebuhn, G., Minckley, R., ... Ricketts, T. H. (2007). Pollination and other ecosystem services produced by mobile organisms: A conceptual framework for the effects of land-use change. Ecology Letters, 10, 299-314.

Martins, C. F., Cortopassi-laurino, M., Koedam, D., \& Imperatriz-fonseca, V. L. (2004). The tree species used for nidification by stingless bees in the Brazilian Caatinga (SERIDÓ, PB; JOÃO CÂMARA, RN). Biota Neotropica, 4(2), 1-8. BN00104022004.

Michener, C. D. (2000). The bees of the world (p. 913). Baltimore, MD: Johns Hopkins University Press.

Michener, C. D., \& Grimaldi, D. A. (1988). The oldest fossil bee: Apoid history, evolutionary stasis, and antiquity of social behavior. Proceedings of the National Academy of Sciences of the United States of America, 85, 6424-6426.

Muriuki, J. H., \& Tsingalia, M. H. (1990). A new population of De Braza's monkey in Kenya. Oryx, 24, 157-162.

Pyper, W. (2001). Six-legged friends. ECOS, 107, 16-17.

Roubik, W. D. (1989). Ecology and natural history of tropical bees (p. 514). UK: Cambridge University Press.
Roubik, D. W. (2006). Stingless bee nesting biology. Apidologie, 37(2), 124-143.

Sakagami, S. F. (1982). Stingless bees. In H. R. Hermann (Ed.), Social insects (pp. 361-423). New York, NY: Academic Press.

Tornyie, F., \& Kwapong, K. P. (2015). Nesting ecology of stingless bees and potential threats to their survival within selected landscapes in the northern Volta region of Ghana. African Journal of Ecology, 53, 398-405.

Tsingalia, H. M. (1988). Animals and the Regeneration of a Canopy Tree in an African Tropical Forest. PhD thesis, Berkeley-University of California.

Tsingalia, H. M. (1990). Habitat severity and patterns of species abundance. African Journal of Ecology., 28, 190-220.

Tsingalia, H. M., \& Kassily, F. N. (2009). The origins of Kakamega Forest grasslands: A critical review. Journal of Human Ecology, 27, 129-135.

Velthius, H. H. W. (1997). The Biology of stingless bees. Utrech, The Netherlands: Utrech University Press.

Vossler, F. G. (2012). Flower visits, nesting and nest defence behaviour of stingless bees (Apidae: Meliponini): Suitability of the bee species for meliponiculture in the Argentinean Chaco region. Apidologie, 43, 139-161.

Wille, A., \& Michener, C. D. (1973). The nest architecture of stingless bees, with special reference to those of Costa Rica. Revista de Biologia Tropical, 21(Suppl. 1), 1-278.

Winfree, R., Griswold, T., \& Kremen, C. (2007). Effect of human disturbance on bee communities in a forested ecosystem. Conservation Biology, 21(1), 213-223.

How to cite this article: Kiatoko N, Van Langevelde F, Raina SK. Forest degradation influences nesting site selection of Afro-tropical stingless bee species in a tropical rain forest, Kenya. Afr J Ecol. 2018;56:669-674. https://doi.org/10.1111/ aje.12491 